\title{
Морфометрический анализ раковин живородки речной Viviparus viviparus (Linne, 1758) водоемов Республики Марий Эл
}

\author{
П.В. Бедова ${ }^{1}$, П.М. Мазуркин ${ }^{2}$ \\ ${ }^{1}$ Марийский государственный университет, Россия, \\ Республика Марий Эл, г. Йошкар-Ола, пл. Ленина 1, bedova@ marsu.ru \\ ${ }^{2}$ Поволжский государственный технологический университет, Россия, \\ Республика Марий Эл, г. Йошкар-Ола, пл. Ленина 3, kaf_po@ mail.ru
}

Аннотация. По измерениям массы и морфометрических параметров раковин живородки речной Viviparus viviparus (Linne, 1758) из разных водоемов Республики Марий Эл доказана высокая адекватность устойчивых закономерностей изменения массы особи от высоты её раковины. При этом биотехнический закон соблюдается для всех изученных популяций. Получено, что морфометрические параметры не имеют корреляции друг с другом. Показана методика идентификации биотехнических закономерностей по статистическим данным измерений. Данные измерений соответствуют закону распределения Гаусса-Лапласа. Сравнение морфометрических параметров самцов и самок живородки речной в целом по исследуемым участкам двух рек за два года показало, что самцы по всем морфометрическим показателям (высота раковины, ширина раковины, высота завитка, высота устья) крупнее самок, при этом разница статистически значима.

Ключевые слова: живородка речная, масса, морфометрические параметры раковины, самцы и самки, распределения, закономерности.

\section{Введение}

Моллюски являются удобными модельными объектами для проведения исследования микроэволюционных процессов. Они характеризуются низким уровнем миграционной активности, их легко собирать в природных местах обитания. Кроме того, раковины моллюсков могут храниться продолжительное время в коллекциях (Хохуткин, 1997).

Живородка речная является европейским видом, обитает в реках, в речных рукавах, пойменных озерах. В водоемах Республики Марий Эл этот вид достигает колоссального количественного развития, в связи с чем становится удобным объектом для проведения популяционных исследований (Бедова, 2010).

Живородка речная является очень изменчивым видом - каждая станция водоема накладывает на форму и параметры раковин свой отпечаток. Изменчивость проявляется в средних размерах раковин, индексах отношения высоты раковины к ширине и других параметрах, a также в толщине стенок, выпуклости оборотов, окраске. В местах обитания с малой жесткостью воды постепенно сформировались разновидности с выпуклыми оборотами, придающими раковинам сходство с болотной живородкой (Жадин, 1928).

Данные об изменчивости отдельных особей из различных частей видовых ареалов расширяют и дополняют представления об их морфологических особенностях и полезны при по- 
строении изучаемой системы. Сравнительной конхологической характеристикой V. viviparus в водоемах бассейна Волги и некоторых рек Украины с 1999 по 2005 годы занималась Л. Н. Хлус (Хлус, 2005).

В Республике Марий Эл у данного вида изучалась структура популяций, зараженность особей партенитами трематод и содержание каротиноидов в тканях (Бедова, 1998 2003,2004,2010). Изучения морфометрических параметров раковин не проводилось. Однако такие исследования в относительно экологически чистых водоемах марийского края актуаль-

ны. В связи с этим, целью наших исследований было проведение морфометрического анализа параметров раковин живородки речной из разных водоемов Республики Марий Эл с применением методов идентификации устойчивых закономерностей при факторном анализе этих количественно измеренных параметров.

Решались следующие задачи:

1) сравнить по выбранным морфометрическим параметрам самцов и самок в популяциях раковин живородки речной из рек Малая Кокшага и Ветлуга;

2) выяснить зависимость морфометрических параметров раковин идентификацией устойчивых законов;

3) определить степень корреляции между морфометрическими признаками в популяциях раковин живородки речной в исследуемых водоемах.

\section{Материал и методы исследования}

Исследования проводились в летний период 2010-2011 гг. на реках Малая Кокшага и Ветлуга. Река Малая Кокшага является 42-м левым притоком реки Волги (от устья) и при этом подвержена антропогенному воздействию. В бассейне реки находятся шесть очистных сооружений и крупный промышленный центр город Йошкар-Ола (Бедова, 2007).

Река Ветлуга является 43-м левым притоком Волги, берет начало в Кировской области, в Республике Марий Эл протекает по Юринскому району. В результате заполнения Чебоксарского водохранилища и поднятия его уровня, в своем устье река напоминает залив. Берега низкие, заболоченные и лесистые. Русло реки Ветлуга очень извилистое (Иванов, 1992).

Сбор раковин живородки речной проводили в литоральной зоне методом учетных площадок (Жадин, 19). На реке Малая Кокшага материал был собран на 13 станциях с учетом характера грунта и прибрежной растительности, в черте города Йошкар-Ола от водозабора до очистных сооружений.

На реке Ветлуга сбор материала проводился на 16 станциях около населенных пунктов Копорулиха, Марьино, Юркино. Всего было промерено 970 раковин живородки речной. 
Обработка статистических данных проводилась в программной среде STATISTICA 6.0. Проверку согласия выборочного распределения с нормальным распределением проводили с помощью критерия Колмогорова-Смирнова с поправкой Лиллиефорса. Сравнение двух несвязанных между собой групп по количественным признакам осуществлялось непараметрическим методом с использованием критерия Вилкоксона-Манна-Уитни.

Анализ связи (наличие корреляции) двух количественных признаков проводили с помощью коэффициента ранговой корреляции по Спирмена (Лакин).

Для сравнения зависимостей изменения массы особи от высоты раковины, а также для факторного анализа, использовался метод идентификации (Мазуркин, 2013; Мазуркин, Кудряшова, 2015; Мазуркин, Михайлова, 2010), включающий фрагменты биотехнического закона (Mazurkin, 2014a,б; 2015а,б) в виде кирпичиков Гилберта (табл. 1).

Таблица 1 - Математические конструкты для составления модели

\begin{tabular}{|c|c|}
\hline $\begin{array}{c}\text { Фрагменты без предыстории } \\
\text { изучаемого явления или процесса }\end{array}$ & $\begin{array}{c}\text { Фрагменты с предысторией } \\
\text { изучаемого явления или процесса }\end{array}$ \\
\hline $\begin{array}{l}y=a x-\text { закон линейного роста или спада } \\
\text { (при отрицательном знаке перед правой сто- } \\
\text { роной формулы линейного изменения) }\end{array}$ & $\begin{array}{l}y=a-\text { закон не влияния принятой объяс- } \\
\text { няющей переменной на показатель, который } \\
\text { имеет собственную предысторию значений }\end{array}$ \\
\hline $\begin{array}{l}y=a x^{b}-\text { закон показательного роста (закон } \\
\text { показательной гибели } y=a x^{-b} \text { не является } \\
\text { устойчивым, из-за бесконечности показателя } \\
\text { при нулевом значении объясняющей пере- } \\
\text { менной) }\end{array}$ & $\begin{array}{l}y=a \exp ( \pm c x)-\text { закон Лапласа в математике } \\
\text { (Ципфа в биологии, Парето в экономике, } \\
\text { Мандельброта в физике) экспоненциального } \\
\text { роста или гибели, относительно которого } \\
\text { Лаплас создал методологию операторного } \\
\text { исчисления }\end{array}$ \\
\hline $\begin{array}{l}y=a x^{b} \exp (-c x) \text { - биотехнический закон в } \\
\text { упрощенной форме (П.М. Мазуркин), когда } \\
\text { показательный рост постепенно получает } \\
\text { экспоненциальное торможение }\end{array}$ & $\begin{array}{l}y=a \exp \left( \pm c x^{d}\right)-\text { закон экспоненциального } \\
\text { роста или гибели в полной форме (конструк- } \\
\text { ции), который имеет интенсивность, не рав- } \\
\text { ную единице (П.М. Мазуркин) }\end{array}$ \\
\hline \multicolumn{2}{|c|}{$\begin{array}{c}y=a x^{b} \exp \left(-c x^{d}\right) \text { - биотехнический закон, } \\
\text { общий для шести конструктов (П.М. Мазуркин) }\end{array}$} \\
\hline
\end{tabular}

В таблице 1 показаны наиболее встречающиеся инварианты (фрагменты). У них впереди могут быть расположены оперативные константы «+» или «-».

Для возможности верификации факторных связей в таблице 2 предложена классификации уровней корреляции. Всего выделены четыре шкалы уровней тесноты связи между учитываемыми факторными связями.

Существующая шкала квантификации тесноты связи между факторами (нет связи, слабая и сильная связь) является грубой и даже примитивной на современном уровне развития информатики и информационных технологий. Нами было доказано, что именно анализ слабых связей, отбрасываемых при линейном моделировании и применении среднеарифметической 
факторной связи по закону Гаусса-Лапласа (так называемого «нормального» распределения), дает новые научные идеи.

Таблица 2 - Уровни тесноты факторных связей

\begin{tabular}{|c|c|c|c|c|}
\hline \multirow[b]{2}{*}{\begin{tabular}{|c|} 
Интервал \\
коэффициента \\
корреляции
\end{tabular}} & \multicolumn{4}{|c|}{ Характер тесноты связи между факторами по шкалам } \\
\hline & $\begin{array}{l}\text { существующая } \\
\text { классификация }\end{array}$ & $\begin{array}{c}\text { шкала для } \\
\text { технических } \\
\text { измерений }\end{array}$ & \begin{tabular}{|c|} 
шкала для \\
прецизионных \\
измерений
\end{tabular} & $\begin{array}{c}\text { шкала для генной } \\
\text { инженерии } \\
\text { (Mazurkin, 2014a) }\end{array}$ \\
\hline 1 & \multirow{6}{*}{ сильная связь } & однозначная & однозначная & однозначная \\
\hline $0.999 \ldots 1.0000$ & & \multirow{4}{*}{ сильнейшая } & \multirow{2}{*}{ почти однозначная } & почти однозначная \\
\hline $0.99 \ldots 1.000$ & & & & чрезвычайно сильная \\
\hline $0.95 \ldots . .0 .99$ & & & сверхсильная & сверхсильная \\
\hline $0.90 \ldots 0.95$ & & & сильнейшая & сильнейшая \\
\hline $0.7 \ldots 0.9$ & & сильная & сильная & сильная \\
\hline $0.5 \ldots .0 .7$ & \multirow{2}{*}{ слабая связь } & средняя & средняя & средняя \\
\hline $0.3 \ldots .0 .5$ & & слабоватая & слабоватая & слабоватая \\
\hline $0.1 \ldots 0.3$ & \multirow{3}{*}{ нет связи } & слабая & слабая & слабая \\
\hline $0.0 \ldots . .0 .1$ & & слабейшая & слабейшая & слабейшая \\
\hline 0 & & нет связи & нет связи & нет связи \\
\hline
\end{tabular}

Однако выяснилось, что первые три шкалы уровней адекватности недостаточно из-за существования более точных табличных моделей. Для многих природных (биологических) объектов и результатов сверхточных физических измерений пришлось ввести еще два интервала уровня адекватности по четвертой шкале таблицы 2.

\section{Результаты исследования}

Морфометрические параметры раковин живородки речной были сняты по следующим показателям: высота раковины, ширина раковины, высоты завитка, высоты устья у самцов и самок отдельно на каждой станции.

За июнь 2010 года на реке Малая Кокшага было промерено 179 особей мужского пола и 235 женского пола. Все исследуемые признаки распределены нормально.

Были рассчитаны средние значения высоты раковины, ширины раковины, высоты завитка, высоты устья у самцов и самок отдельно на каждой станции. Достоверно отличаются высота и ширина раковины, а также высота завитка у разных полов на станции № 2; высота раковины и высота завитка на № 9; высота раковины, завитка и устья на станции № 10.

Сравнение морфометрических параметров самцов и самок живородки речной в целом по исследуемому участку показало, что самцы по всем морфометрическим показателям (высота раковины, ширина раковины, высота завитка, высота устья) крупнее самок. Разница статистически значима (табл. 3). 
Таблица 3 - Сравнительный анализ морфометрических параметров раковин V. viviparus самцов и самок в целом по исследуемому участку реки Малая Кокшага (2010 год).

\begin{tabular}{|l|c|c|c|c|c|c|}
\hline \multirow{2}{*}{ Параметры } & \multicolumn{2}{|c|}{ Самцы $(\mathbf{n = 1 7 9 )}$} & \multicolumn{2}{c|}{ Самки $(\mathbf{n = 2 3 5})$} & \multirow{2}{*}{$\mathbf{t}$} & \multirow{2}{*}{$\mathbf{p}$} \\
\cline { 1 - 6 } & $\boldsymbol{x} \pm \boldsymbol{m} \boldsymbol{x}$ & $\boldsymbol{S D}$ & $\boldsymbol{x} \pm \boldsymbol{m} \boldsymbol{x}$ & $\boldsymbol{S D}$ & & \\
\hline Высота раковины & $2.08 \pm 0.038$ & 0.501 & $1.87 \pm 0.043$ & 0.659 & 3.642 & 0.0014 \\
\hline Ширина раковины & $1.78 \pm 0.028$ & 0.370 & $1.63 \pm 0.032$ & 0.485 & 3.460 & 0.0029 \\
\hline Высота устья & $1.29 \pm 0.026$ & 0.353 & $1.15 \pm 0.030$ & 0.462 & 3.488 & 0.0012 \\
\hline Высота завитка & $1.24 \pm 0.018$ & 0.238 & $1.14 \pm 0.019$ & 0.287 & 3.894 & 0.0022 \\
\hline
\end{tabular}

Последующим шагом исследований был анализ данных за 2010 год по реке Малая Кокшага, в частности влияние высоты $h$ раковины на массу $m$ особи. Выяснилось, что эта зависимость подчиняется биотехническому закону из таблицы 1 и отображается рисунком 1:

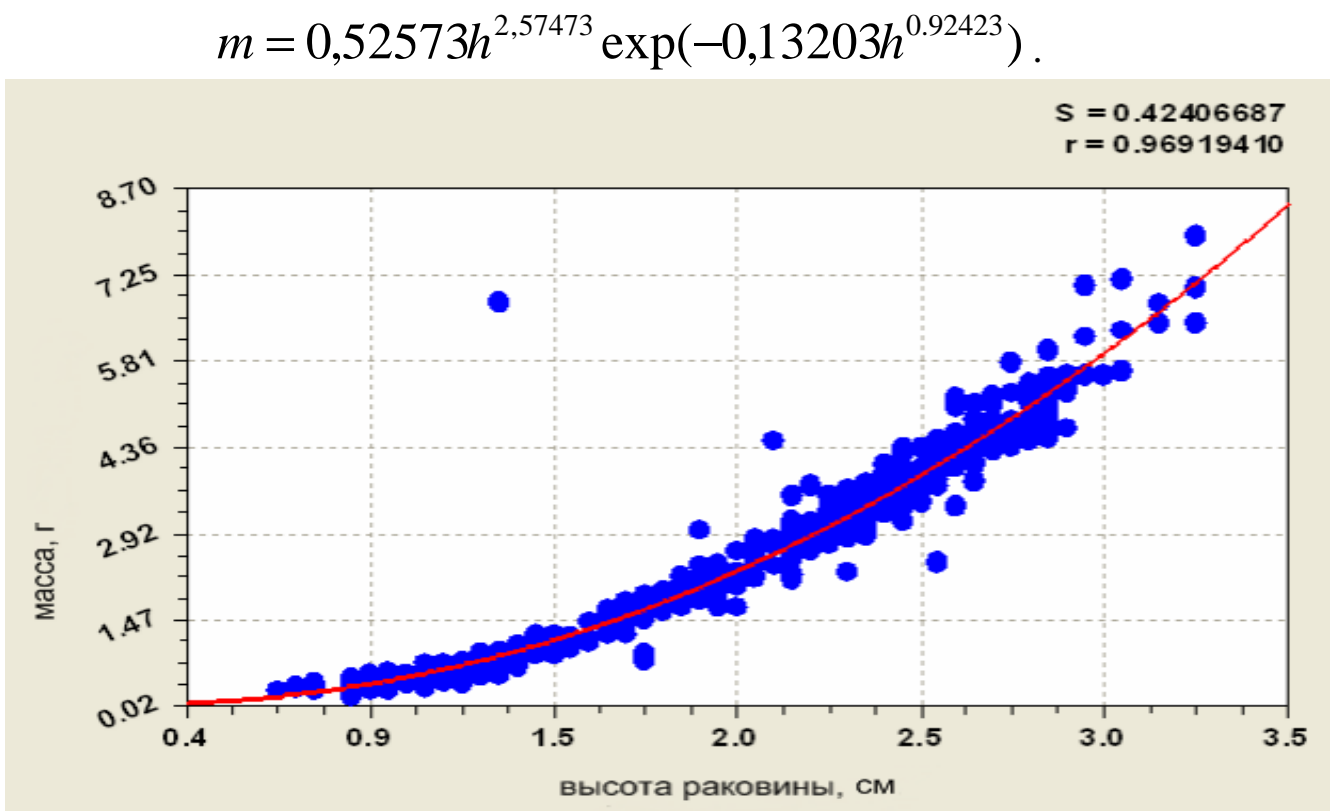

Рисунок 1 - Зависимость массы особи от высоты раковины V. viviparus (2010 г.) на реке Малая Кокшага (в правом верхнем углу: $S$ - дисперсия; $r$ - коэффициент корреляции)

Коэффициент корреляции между высотой раковины и массой особи живородки речной равен 0.9692, что согласно классификации таблицы 2 говорит о наличии уровня адекватности «сверхсильная» факторная связь между этими признаками. При этом, как видно из распределения точек на рисунке 1, одно значение резко выбрасывается вверх. Поэтому её можно было исключить, что повысит значение коэффициента корреляции.

Расчеты данных за 2011 год реки Малая Кокшага по критерию Колмогорова-Смирнова с поправкой Лиллиефорса показали, что все исследуемые параметры так же распределены нормально. За июнь 2011 года на реке Малая Кокшага было промерено 164 особи.

Сравнение морфометрических параметров между самцами и самками на станциях показало, что достоверные отличия зарегистрированы на станциях № 4, № 5, № 8, № 9 по признаку «высота раковины». 
На станции № 9 по параметрам: ширина раковины, высота завитка, высота устья. На станции № 12 по параметру высота устья. Анализ раковин на станциях № 3 и № 6 не проводили, вследствие недостаточной выборки на этих станциях. При сравнении морфометрических параметров самцов и самок в целом по исследуемому участку за 2011 год показано, что самцы по всем морфометрическим показателям крупнее самок (табл.4).

Таблица 4 - Сравнительный анализ морфометрических параметров самцов и самок $V$. viviparus в целом по исследуемому участку реки Малая Кокшага (2011 год).

\begin{tabular}{|l|c|c|c|c|c|c|}
\hline \multirow{2}{*}{\multicolumn{1}{c|}{ параметры }} & \multicolumn{2}{|c|}{ самцы(n=69) } & \multicolumn{2}{c|}{ самки(n=95) } & \multirow{2}{*}{ t } & \multirow{2}{*}{ p } \\
\cline { 1 - 5 } & $\mathbf{x} \pm \mathbf{m x}$ & $\mathbf{S D}$ & $\mathbf{x} \pm \mathbf{m x}$ & $\mathbf{S D}$ & & \\
\hline Высота раковины & $2.33 \pm 0,05$ & 0.41 & $1.74 \pm 0.08$ & 0.79 & 5.57 & $\mathbf{0 . 0 0 0 0 0 1}$ \\
\hline Ширина раковины & $1.95 \pm 0,04$ & 0.30 & $1.51 \pm 0.06$ & 0.60 & 5.57 & $\mathbf{0 . 0 0 0 0 0 1}$ \\
\hline Высота завитка & $1.34 \pm 0,03$ & 0.22 & $1.04 \pm 0.04$ & 0.44 & 5.30 & $\mathbf{0 . 0 0 0 0 0 1}$ \\
\hline Высота устья & $1.52 \pm 0,04$ & 0.30 & $1.12 \pm 0.06$ & 0.56 & 5.49 & $\mathbf{0 . 0 0 0 0 0 1}$ \\
\hline
\end{tabular}

Анализ данных за 2011 год по реке Малая Кокшага, показал, что зависимость массы особи от размера высоты раковины подчиняется формуле 3 и отображается рисунком 2.

$$
m=0,87078 h^{4,24853} \exp \left(-1.11074 h^{0.82107}\right) .
$$

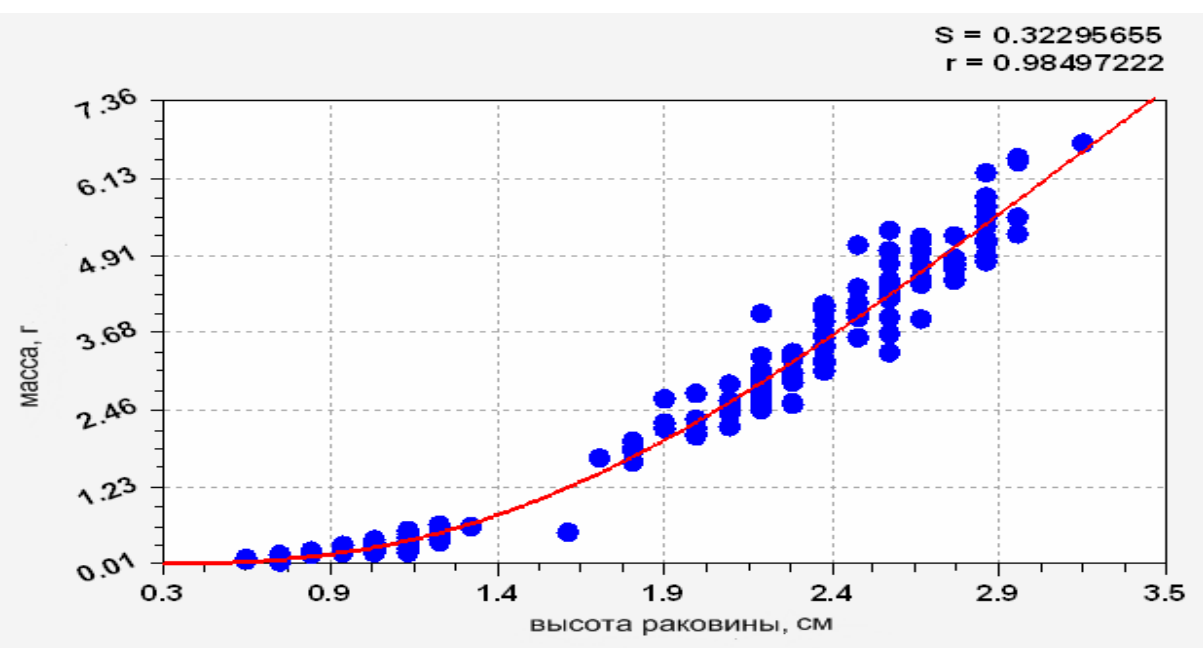

Рисунок 2 - Зависимость массы особи от высоты раковины V. viviparus (2011 г.) на реке

Малая Кокшага (в правом верхнем углу: $S$ - дисперсия; $r$ - коэффициент корреляции)

Коэффициент корреляции также очень высок и равен 0.9850, что указывает о присутствии сильнейшей связи между признаками высота раковины и масса особи в 2011 году.

Из популяции V. viviparus реки Ветлуга было промерено 393 особи. Анализ параметров раковин живородки речной реки Ветлуга за июнь 2011 года по критерию КолмогороваСмирнова с поправкой Лиллиефорса показали, что все исследуемые параметры также распределены нормально.

На станциях № 3, № 7, № 12, анализ морфометрических параметров между самцами и самками показал достоверные отличия по всем признакам. На станциях № 11 и № 13 по пара- 
метрам: высота раковины, ширина раковины, высота устья. На станции №1 4 по параметру высота устья. Подвергнуть анализу станции № 4 и № 16 не удалось вследствие недостаточной выборки на этих станциях. В целом по исследуемому участку по всем морфометрическим показателям самцы крупнее самок (табл. 5). Разница статистически значима.

Таблица 5 - Сравнительный анализ морфометрических параметров самцов и самок $V$. viviparus в целом по исследуемому участку реки Ветлуга (2011 год).

\begin{tabular}{|c|c|c|c|c|c|c|}
\hline \multirow{2}{*}{ параметры } & \multicolumn{2}{|c|}{ самцы $(n=123)$} & \multicolumn{2}{|c|}{ самки $(\mathrm{n}=270)$} & \multirow{2}{*}{$\mathrm{t}$} & \multirow{2}{*}{$\mathrm{p}$} \\
\hline & $\mathrm{x} \pm \mathrm{mx}$ & SD & $\mathrm{x} \pm \mathrm{mx}$ & SD & & \\
\hline Высота раковины & $2.01 \pm 0,5$ & 0.31 & $2.01 \pm 0.08$ & 0.57 & 0.15 & 0.000001 \\
\hline Ширина раковины & $1.76 \pm 0,04$ & 0.24 & $1.75 \pm 0.06$ & 0.44 & 0.24 & 0.000001 \\
\hline Высота завитка & $1.22 \pm 0,03$ & 0.16 & $1.19 \pm 0.04$ & 0.27 & 0.98 & 0.000001 \\
\hline Высота устья & $1.26 \pm 0,04$ & 0.22 & $1.26 \pm 0.06$ & 0.40 & 0.01 & 0.000001 \\
\hline
\end{tabular}

Анализ зависимости массы особи от высоты раковины также дал положительный результат: коэффициент корреляции равен 0.9829 , что является следствием сильнейшей взаимосвязи между факторами по формуле 4. Данная зависимость отображается рисунком 3.

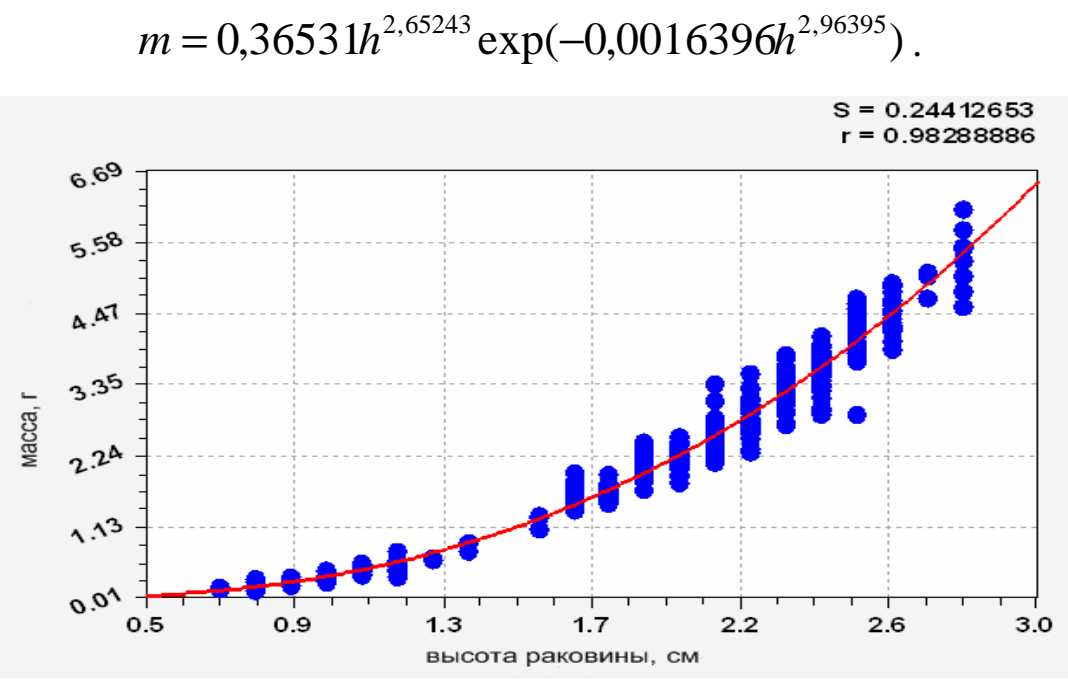

Рисунок 3 - Зависимость массы особи от высоты раковины V. viviparus (2011 г.) на реке

Ветлуга (в правом верхнем углу: $S$ - дисперсия; $r$ - коэффициент корреляции).

Коэффициент корреляции равен 0.9829 и согласно данным из таблицы 2 этот факт указывает на сверхсильную связь между признаками. Поэтому теснота связи между массой и высотой раковины соответствует классификации уровня адекватности по четвертому столбцу таблицы 2.

\section{Обсуждение результатов исследований}

Коэффициент корреляции во всех трех зависимостях виде биотехнического закона проф. П.М. Мазуркина массы особи от высоты раковины очень высок (рис.1, 2, 3). В связи с этим, было решено совместить все три графика для сравнения в одной и той же оси координат (рис. 4). В расчетах высоту принимали с шагом в 0.1 мм. 


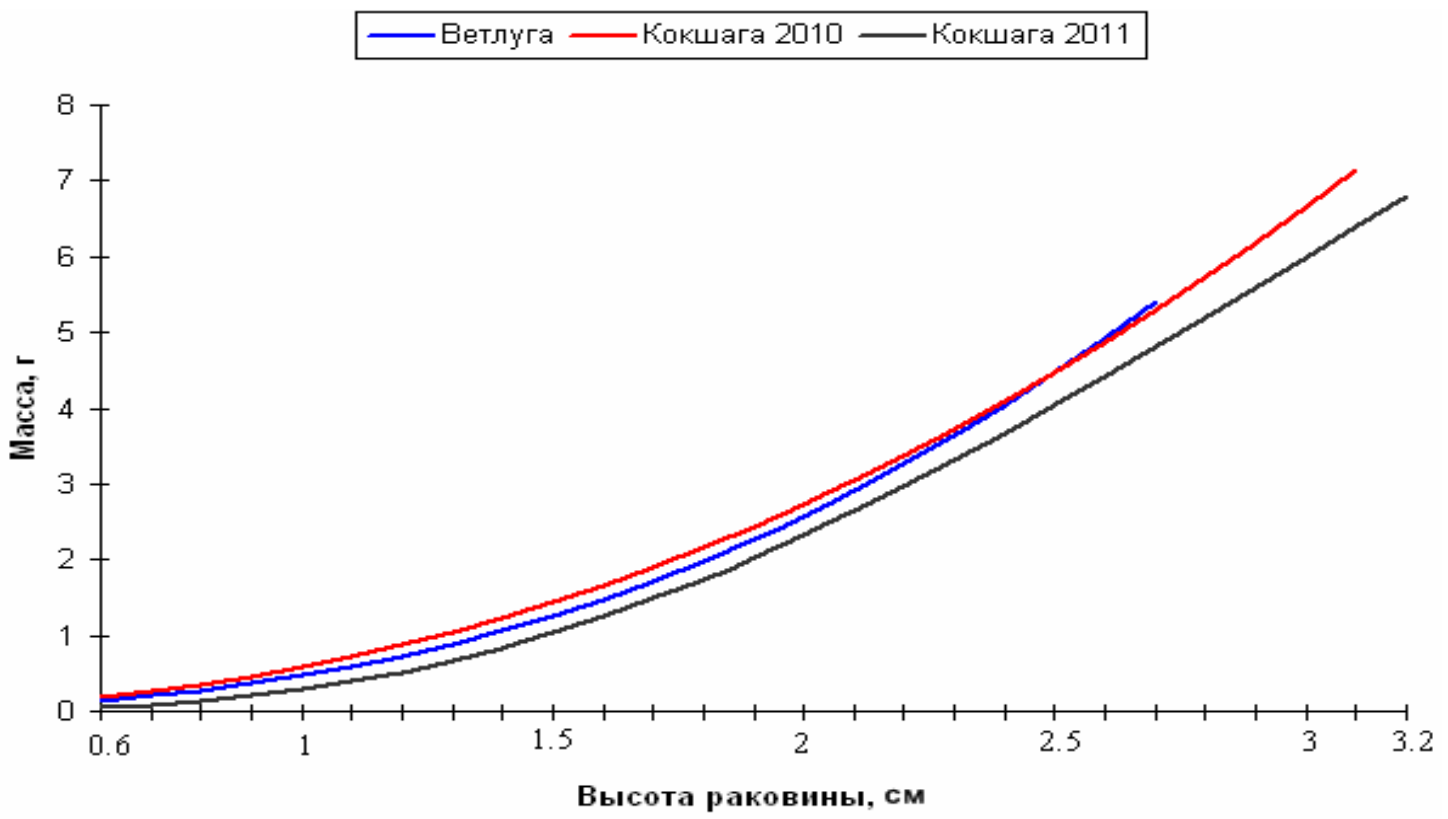

Рисунок 4 - Зависимость массы особи от высоты раковины в популяциях $V$. viviparus в исследуемых водоемах

По рисунку 4 видно, что кривые массы от высоты раковины в реках Ветлуга за 2011 год и Малой Кокшаги за 2010 год лежат в одной области, практически накладываются друг на друга. Графики двух лет исследований на реке Малая Кокшага лежат практически параллельно друг другу. Если в 2010 году при высоте раковины в 1 см масса особи составляла около 0.7-0.8 г, то в 2011 году при той же высоте масса особи составила только 0.3-0.4 г. Повидимому, уменьшение массы моллюсков при одинаковых размерах, связанно с ухудшением условий обитания, в частности, с интенсивной застройкой набережной в г. Йошкар-Ола.

Факторный анализ между всеми морфометрическими параметрами показал, что в пределах одного биотопа различаются (табл. 6) очень слабо. Такое сохранение в динамике развития и роста по метрическим конхологическим признакам в пределах одного водоема для Поволжского региона доказал В. И. Жадин (Жадин, 1928).

В целом, общая структура корреляционных связей изученных конхологических параметров в выборках из всех популяций не имеет сходный характер. Метрические показатели в популяциях реки Малая Кокшага за 2010 и 2011 года оказались скоррелированными между собой очень слабо. Популяция раковин живородки речной реки Малая Кокшага в 2010 году по отношению к популяции реки Ветлуга проявляет слабейшую тесноту связи в парах: ширина раковины - высота завитка и ширина раковины - высота устья. Популяция реки Малая Кокшага в 2011 году по отношению к популяции реки Ветлуга проявляет слабейшую связь по всем параметрам кроме пар: высота раковины - высота устья, высота завитка - высота раковины, высота завитка - высота устья, где проявляются только слабые связи. 
Таблица 6 - Коэффициенты корреляции бинарных связей между морфометрическими параметрами раковин V.viviparus из исследуемых водоемов

\begin{tabular}{|c|c|c|c|c|c|}
\hline \multicolumn{2}{|c|}{$\begin{array}{c}\text { Морфологические } \\
\text { параметры }\end{array}$} & $\begin{array}{c}\text { Высота } \\
\text { раковины }\end{array}$ & $\begin{array}{c}\text { Ширина } \\
\text { раковины }\end{array}$ & $\begin{array}{c}\text { Высота за- } \\
\text { витка }\end{array}$ & $\begin{array}{c}\text { Высота } \\
\text { устья }\end{array}$ \\
\hline \multicolumn{6}{|c|}{ Малая Кокшага 2011 г. } \\
\hline Высота раковины & \multirow{4}{*}{$\begin{array}{c}\text { Малая } \\
\text { Кокшага } \\
2010 \text { г. }\end{array}$} & - & 0,1924 & 0,2331 & 0,1738 \\
\hline Ширина раковины & & 0,2309 & - & 0,2528 & 0,1921 \\
\hline Высота завитка & & 0,2167 & 0,2008 & - & 0,1885 \\
\hline Высота устья & & 0,1924 & 0,1877 & 0,2234 & - \\
\hline \multicolumn{6}{|c|}{ Ветлуга 2011г. } \\
\hline Высота раковины & \multirow{4}{*}{$\begin{array}{c}\text { Малая } \\
\text { Кокшага } \\
2010 \text { г. }\end{array}$} & - & 0,1290 & 0,1120 & 0,1026 \\
\hline Ширина раковины & & 0,1006 & - & 0,0885 & 0,0924 \\
\hline Высота завитка & & 0,1314 & 0,1410 & - & 0,1155 \\
\hline Высота устья & & 0,1061 & 0,1234 & 0,1021 & - \\
\hline \multicolumn{6}{|c|}{ Ветлуга 2011г. } \\
\hline Высота раковины & \multirow{4}{*}{$\begin{array}{c}\text { Малая } \\
\text { Кокшага } \\
2011 \text { г. }\end{array}$} & - & 0,0755 & 0,0809 & 0,1142 \\
\hline Ширина раковины & & 0,0610 & - & 0,0451 & 0,0907 \\
\hline Высота завитка & & 0,1031 & 0,0998 & - & 0,1341 \\
\hline Высота устья & & 0,0999 & 0,0877 & 0,0928 & - \\
\hline
\end{tabular}

Примечание: курсивом выделены значения коэффициента корреляции, характеризующие слабейший уровень адекватности по классификации таблицы 2.

Таким образом, анализ морфометрических параметров раковин показал, что конхологические параметры $V$. viviparus рек Ветлуга и Малая Кокшага слабо или очень слабо связаны между собой. С коэффициентом корреляции менее 0,3 по данным таблицы 5 можно утверждать, что размеры и форма раковин живородки речной, по крайне мере для одного водоема, изменяются хаотично.

\section{Выводы}

Результаты проведенных исследований по анализу морфометрических параметров раковин живородки речной Viviparus viviparus (Linne, 1758) на реке Малая Кокшага в черте города Йошкар-Ола и на реке Ветлуга позволяют сделать выводы:

1) на период исследований в исследуемых водоемах самцы по всем морфометрическим показателям крупнее самок, при этом разница статистически значима;

2) выявлена закономерность изменения массы особи в зависимости от высоты раковины по биотехническому закону: коэффициент корреляции во всех трех исследуемых популяциях раковин живородки речной достаточно высок и колеблется от 0.96 до 0.98 ;

3) факторный анализ выявил слабые связи между морфометрическими признаками исследуемых популяций: от 0.23 между факторами «ширина раковины - высота раковины» популяций реки Малая Кокшага (2010-2011 гг.), до 0.04 между параметрами «ширина раковины высота завитка» между популяциями рек Малая Кокшага (2011 г.) и Ветлуга (2011 г.). 


\section{Список литературы}

1. Бедова П.В., Колупаев Б.И. Использование моллюсков в биологическом мониторинге состояния водоемов // Экология. - 1998. - N 5. - С. 410-411.

2. Бедова П.В. Структура популяции живородки речной (Viviparus viviparus L.) реки Малая Кокшага //Актуальные экологические проблемы Республики Татарстан. Матер. V республиканской науч. конф. - Казань: Отечество, 2003. - С.83-84.

3. Бедова П.В., Гаврилова Е.Ю. Влияние трематодной инвазии на содержание каротиноидов в тканях моллюска Viviparus viviparus (Linne, 1758) реки Малая Кокшага // Современные проблемы физиологии и биохимии водных организмов. - Петрозаводск: изд-во Института биологии КарНЦ РАН, 2004. - С. 14-15.

4. Бедова П.В. Комплексная оценка качества воды реки Малая Кокшага в черте г. ЙошкарОлы // Экология города Йошкар-Олы.- Йошкар-Ола, 2007. - С.79-87.

5. Бедова П.В. Состояние популяции живородки речной Viviparus viviparus L. (Mollusca, Gastropoda) реки Малая Кокшага // Журнал Сибирского Федерального университета. Биология. - 2010. -№ 3. - С. 335-341.

6. Жадин В. И. Исследование по экологии изменчивости Vivipara fasciata Mill. - Саратов: 1928. - 94 c.

7. Жадин В. И. Моллюски пресных и солоноватых вод СССР. - М.,Л.: Изд-во АН СССР, 1952. $-376 \mathrm{c}$.

8. Иванов Н.В. География Марийской АССР.- Йошкар-Ола: Периодика, 1992. - 104 с.

9. Лакин Г.Ф. Биометрия - М.: Высш. шк., 1990 - 348 с.

10. Мазуркин П.М. Коррелятивная вариация: Учеб. Пособие для студентов. - Йошкар-Ола: Поволжский ГТУ, 2013. - 120 с.

11. Мазуркин П.М., Кудряшова А.И. Динамика онтогенеза листьев дерева.- Йошкар-Ола: ПГТУ, 2015. - $172 \mathrm{c}$.

12. Мазуркин П. М., Михайлова С.И. Территориальное экологическое равновесие = Territprial ecological balance: аналит. обзор; Учреждение Рос. акад. наук Гос. публич. науч.-техн. бка Сиб. отд-ния РАН, Марийс. гос. техн. ун-т. Новосибирск : ГПНТБ СО РАН, 2010. 430 c. (Сер. Экология. Вып. 94).

13. Хлус Л.Н. Сравнительная конхологическая характеристика Viviparus viviparus L. (Gastropoda, Vivipariformes: Viviparidae) водоемов бассейна Волги и некоторых рек Украины // Биоресурсы и биоразнообразие экосистем Поволжья: прошлое, настоящее, будущее. - Саратов: Изд-во Сарат. ун-та, 2005. - С. 236-238.

14. Хохуткин И. М. Структура изменчивости видов на примере наземных моллюсков / Отв. ред. Л.Н. Добринский. - Екатеринбург: УрО РАН, 1997. - 176 с.

15. Mazurkin P.M. Identification of the wave patterns of behavior $/ / 14^{\text {th }}$ International multidisciplinary scientific geoconferenct \& SGEM2014. GeoConference jn NANO, BIO AND GREEN - TECHNOLOGIES FOR A SUSTAINABLE FUTURE. Conference proceedincs. Volume 1. Section Advances in Biotechnology. 17-26 June 2014. Albena, Bulgaria. P. 373-380.

16. Mazurkin P.M. Method of identification // $14^{\text {th }}$ International multidisciplinary scientific geoconferenct \& SGEM2014. GeoConference jn NANO, BIO AND GREEN - TECHNOLOGIES FOR A SUSTAINABLE FUTURE. Conference proceedincs. Volume 1. Section Advances in Biotechnology. 17-26 June 2014. Albena, Bulgaria. P. 427-434.

17. P.M. Mazurkin. Invariants of the Hilbert Transform for 23-Hilbert Problem, Advances in Sciences and Humanities. Vol. 1, No. 1, 2015, pp. 1-12. doi: 10.11648/j.ash.20150101.11.

18. P.M. Mazurkin. Wavelet Analysis Statistical Data. Advances in Sciences and Humanities. Vol. 1, No. 2, 2015, pp. 30-44. doi: 10.11648/j.ash.20150102.11. 